\title{
Integrated Management of Childhood Illness With the Focus on Caregivers: an Integrative Literature Review
}

\author{
Vania Daniele Paranhos ${ }^{1}$ \\ Juliana Coelho Pina ${ }^{2}$ \\ Débora Falleiros de Mello ${ }^{3}$
}

\begin{abstract}
The Integrated Management of Childhood Illness (IMCI) strategy addresses the diseases most prevalent in infancy, the reception of the child and family, and the comprehension the problem and effective procedures. The aim was to identify, between 1998 and 2008, publications relating to the IMCI strategy focusing on the caregiver. This study is an Integrative literature review in the Pubmed, Lilacs and Scielo databases. The caregivers knew one or more warning signs for acute respiratory infection, but not for diarrhea. Pneumonia was perceived as a serious childhood disease. Communication skills among health professionals trained in the IMCI strategy were different to those in untrained professionals. The followup of the health of the child is higher according to the education level of the caregiver, and according to the medications supplied in the consultation and in the follow-up. Regarding the health of the child it is relevant to focus on the IMCI strategy, favoring experiences that include the family in the care.
\end{abstract}

Descriptors: Child Health; Integrated Management of Childhood Illness; Caregivers.

\footnotetext{
${ }^{1}$ Nursing undergraduate student, Escola de Enfermagem de Ribeirão Preto, Universidade de São Paulo, WHO Collaborating Centre for Nursing Research Development, SP, Brazil. Scholarship holder of the Scientific Initiation Program at the Conselho Nacional de Desenvolvimento Científico e Tecnológico (CNPq). E-mail: vaniadaniparanhos@gmail.com.

${ }^{2}$ RN, M.Sc. in Public Health, Escola de Enfermagem de Ribeirão Preto, Universidade de São Paulo, WHO Collaborating Centre for Nursing Research Development, SP, Brazil. E-mail: jcoelho@eerp.usp.br.

${ }^{3}$ RN, Free Lecture, Associate Professor, Escola de Enfermagem de Ribeirão Preto, Universidade de São Paulo, WHO Collaborating Centre for Nursing Research Development, SP, Brazil. E-mail: defmello@eerp.usp.br.
}

Corresponding Author:

Débora Falleiros de Mello

Universidade de São Paulo. Escola de Enfermagem de Ribeirão Preto.

Av. dos Bandeirantes, 3900

Bairro Monte Alegre

CEP: 14040-902 Ribeirão Preto, SP, Brasil

E-mail: defmello@eerp.usp.br 


\title{
Atenção integrada às doenças prevalentes na infância e o enfoque nos cuidadores: revisão integrativa da literatura
}

A estratégia atenção integrada às doenças prevalentes na infância (AIDPI) aborda as doenças de maior prevalência na infância, o acolhimento da criança e família, a compreensão do problema e procedimentos eficazes. O objetivo foi identificar, entre 1998 e 2008, publicações relativas à estratégia AIDPI com enfoque no cuidador. Foi realizada revisão integrativa com evidências da literatura, nas bases de dados PubMed, LILACS e SciELO. Os cuidadores sabem um ou mais sinais de alarme para infecção respiratória aguda, mas não para diarreia. A pneumonia é percebida como grave doença infantil. As habilidades comunicativas entre os profissionais de saúde capacitados na estratégia AIDPI e os não capacitados são diferentes. O seguimento da saúde da criança é maior de acordo com a escolaridade do cuidador, os medicamentos fornecidos na consulta e o retorno. Na saúde da criança, é relevante enfocar a estratégia AIDPI, favorecendo vivências que incluam a família no cuidado.

Descritores: Saúde da Criança; Atenção Integrada às Doenças Prevalentes na Infância; Cuidadores.

\section{La atención integrada de las enfermedades prevalentes en la infancia y el enfoque en los cuidadores: revisión integradora de la literatura}

\begin{abstract}
La estrategia Atención Integrada a las Enfermedades Prevalentes en la Infancia (AIEPI) aborda las enfermedades de mayor prevalencia en la infancia, el acogimiento del niño y de la familia, la comprensión del problema y los procedimientos eficaces. El objetivo fue identificar, entre 1998 y 2008, publicaciones relacionadas a la estrategia AIEPI con enfoque en el cuidador. Revisión integradora con evidencias en la literatura, en las bases de datos Pubmed, Lilacs y Scielo. Los cuidadores conocen una o más señales de alarma para infección respiratoria aguda, pero no para diarrea. La neumonía es percibida como una grave enfermedad infantil. Las habilidades comunicativas entre los profesionales de la salud capacitados en la estrategia AIEPI y los no capacitados son diferentes. El seguimiento de la salud del niño es mayor de acuerdo con la escolaridad del cuidador, los medicamentos ofrecidos en la consulta y el retorno. En la salud del niño es relevante enfocar la estrategia AIEPI, favoreciendo vivencias que incluyan a la familia en el cuidado.
\end{abstract}

Descriptores: Salud del niño; Atención Integrada a las Enfermedades Prévalentes de la Infancia; Cuidadores.

\section{Introduction}

The programs and policy guidelines aimed at child health have had, as their main goal, the reduction of infant mortality, considered a major indicator of the social and economic development of a country or region. Globally, the current literature shows that nearly 11 million deaths of children under five years of age occur annually. Of these, about 4 million occur in the first month of life and most could be prevented if all children were covered by existing interventions, but this, in many countries, is beyond the reach of most children, highlighting the importance of equity, both among countries and within a country(1).

In this scenario, a set of infectious diseases continues to be the cause of mortality of 20 to $30 \%$ of children under five years of age worldwide, and, in some American countries, causing up to $50 \%$ of the total deaths in this age group $^{(1)}$. 
Considering the integrality of health care actions for the child, the monitoring of infant health is a broad and complex process, involving promotional, preventive and therapeutic measures, interactions with the child, the family, the health services and other social sectors. A strategy that involves all these aspects should include the training of health teams, the structuring of the health system and the valorization of family and community experiences $^{(2)}$.

The Integrated Management of Childhood Illness (IMCI) strategy, developed by the Pan American Health Organization (PAHO), the World Health Organization (WHO) and the United Nations Children's Fund (UNICEF), was established in 1996 with the following objectives: to reduce mortality of children under 5 years of age; to decrease the incidence and/or severity of cases of infectious diseases, especially pneumonia, diarrhea, intestinal parasites, meningitis, tuberculosis, malaria, measles, as well as nutritional disorders; to ensure an adequate quality of care health for children under 5 years, in health services, domiciles and in the community; to strengthen health promotion and preventive measures in infancy ${ }^{(3-4)}$.

The IMCI strategy considers, in a simultaneous and integrated way, the set of diseases most prevalent in infancy, and proposes an approach to child health with the systematization of clinical care and the integration of curative actions with preventive measures and health promotion $^{(5)}$. It aims to promote a rapid and significant reduction in infant mortality through the training of health professionals. According to the strategy, it therefore rests with the health professional to welcome children and their companions, to comprehend the extent of the afflicting problem, and to propose procedures that are easy to apply and have proven effectiveness. For this, it is considered as extremely important to establish a channel of communication with the families, so they can grasp the recommendations regarding treatment and the care to be provided in the domicile, as well as memorizing the signals indicative of gravity that require the immediate return of the child to the health service ${ }^{(6)}$.

In the present environment of scientific divulgation recent publications were observed that address maternal satisfaction with the care provided to the child(7) and the care of the child showing the way the professionals deal with the mothers ${ }^{(8)}$. No specific studies of the IMCI strategy with the focus on the caregivers were found. Thus, this study will contribute by adding to the reflection with the focus on the caregiver, as proposed by IMCI.

Many issues related to IMCI are currently being discussed, opening up possibilities for better comprehension and identification of gaps in knowledge. This study aims to identify, in national and international journals between 1998 and 2008, publications relating to the IMCI strategy with the focus on the caregiver (mothers and/or family members), characterizing how this thematic is related to integral care for the health of the child.

\section{Method}

This is an integrative literature review. The integrative literature review is considered an instrument of evidence-based practice (EBP) and has the potential to construct grounded and uniform knowledge for the performance of quality clinical practice. The steps that compose this integrative review are: identification of the theme and selection of the research question, searching digital databases, establishment of criteria for inclusion and exclusion of studies, search of the full texts, definition of the information to be extracted from the selected studies, categorization and evaluation of the included studies, interpretation of the results, and presentation of the review/synthesis of knowledge ${ }^{(9)}$.

The guiding question used was: what is the scientific knowledge about IMCI produced in the last ten years, focusing on the caregivers (mothers and/or family members)? The following keywords were used: aidpi, imci, aiepi, aidpi e mãe, aidpi e família, aiepi e madre, imci and mother, imci and caregivers, imci and family, prevenção e doenças e infância, promoção e saúde e infância, in the Pubmed, Lilacs and Scielo databases.

The studies included met the following inclusion criteria: a summary available in the above databases, language of publication in Portuguese, English or Spanish; publication period from January 1998 to July 2008 and thematics on IMCI, noting the inclusion of caregivers (mothers and/or family members).

From the reading of the abstracts, the studies that met the inclusion criteria were selected and their full versions located. Studies with various designs and scientific evidence were included, due to the characteristic of the guiding question, which is not related to the effectiveness of an intervention, which necessarily would lead to experimental studies with high levels of evidence, but to the breadth of the knowledge produced about a determined theme. Studies of literature reviews and studies of interviews with health professionals, in which the theme was no longer the IMCI strategy with the focus on the caregiver, were excluded.

Figure 1 shows the databases, year, origin and authors of the studies analyzed. 


\begin{tabular}{|c|c|c|c|}
\hline Database & Year & Origin & Author \\
\hline Pubmed/ Lilacs & 2006 & Brazil & Amorim, Damasceno, Trindade, Aben-Athar ${ }^{(10)}$ \\
\hline Pubmed/ Lilacs/Scielo & 2006 & Brazil & Prado, Fujimori(11) \\
\hline Scielo & 2008 & Kenya & Irimu, Nduati, Wafula, Lenja ${ }^{(12)}$ \\
\hline Pubmed/ Lilacs & 2006 & Brazil & Paulo, Madeira ${ }^{(13)}$ \\
\hline Pubmed & 2008 & Pakistan & Zaman, Ashraf, Martines ${ }^{(14)}$ \\
\hline Pubmed & 2004 & Brazil & Pelto, Santos, Gonçalves, Victora, Martines, Habicht'(15) \\
\hline Pubmed & 2001 & Brazil & Santos, Victora, Martines, Gonçalves, Gigante, Valle, Pelto et al ${ }^{(16)}$ \\
\hline Pubmed & 2005 & Brazil & Cunha, Santos, Martines ${ }^{(17)}$ \\
\hline Pubmed & 2004 & South Africa & Chopra, Patel, Cloete, Sanders, Peterson ${ }^{(18)}$ \\
\hline Pubmed & 2007 & Benin & Kelly, Rowe, Onikpo, Lama, Cokou, Deming ${ }^{(19)}$ \\
\hline Pubmed & 2004 & Mexico & Lopes-Flores, Barquera-Cervera, Kageyama-Escobar ${ }^{(20)}$ \\
\hline Pubmed & 2005 & Nigeria & Adegdoyega, Onayade, Salawu ${ }^{(21)}$ \\
\hline Pubmed & 2003 & Sudan & Al Fadil, Alrahman, Cousens, Bustreo, Shadoul, Farhoud, et al (22) \\
\hline Pubmed & 2003 & Ecuador & Kalter, Salgado, Moulton, Nieto, Contreras, Egas, et al(23) \\
\hline
\end{tabular}

Figure 1 - Distribution of bibliographic references showing the databases, year, country of publication and authors.

Studies were analyzed according to their design, the methodology employed, the results and conclusions. It was sought to analyze whether the methodology was adequate to achieve their aims and the level of scientific evidence afforded. The studies were analyzed as to how they focused the caregivers in the context of the IMCI strategy - for example, whether the focus was on guidance given by a health professional to the caregiver, on the capacity of the caregiver to remember the guidelines and practice them, or on the integration between the knowledge of the professional and the caregiver. Furthermore the results were analyzed to determine whether they supported the conclusions of the studies.
After analyzing the full texts, a synthesis of data was performed, contemplating title, author, aim, methodology, results and conclusions. The selection and analysis of the studies were conducted by two researchers and subsequently compared, with 14 articles in total selected and analyzed. The presentation of data was carried out descriptively, proceeding to the categorization of data, extracted from the selected studies, into thematic groups, by the identification of variables of interest and key concepts, as proposed in the specific literature regarding the integrative literature review ${ }^{(24)}$.

\section{Results}

Figure 2 presents the references analyzed in this integrative literature review.

\begin{tabular}{|l|l|l|l|l|}
\hline \multicolumn{1}{|c|}{ Author } & \multicolumn{1}{|c|}{ Aims } & \multicolumn{1}{c|}{ Type of study } & \multicolumn{1}{c|}{ Results } & \multicolumn{1}{c|}{ Conclusions } \\
\hline $\begin{array}{l}\text { Amorim, } \\
\text { Damasceno, } \\
\text { Trindade, Aben- } \\
\text { Athar }{ }^{(10)}\end{array}$ & $\begin{array}{l}\text { To evaluate the knowledge of } \\
\text { parents or guardians regarding } \\
\text { the warning signs in Acute } \\
\text { Respiratory Infection (ARI) and } \\
\text { Acute Diarrheal IIIness (ADI), in } \\
\text { a Brazilian outpatient pediatric } \\
\text { clinic. }\end{array}$ & $\begin{array}{l}\text { Cross-sectional } \\
\text { Descriptive- } \\
\text { exploratory }\end{array}$ & $\begin{array}{l}\text { 51.74\% of the caregivers knew } \\
\text { one or more warning signs for } \\
\text { ARI and 50\% knew one or more } \\
\text { warning signs for ADI. Mothers } \\
\text { knew the importance of the } \\
\text { administration of liquids and food. }\end{array}$ & $\begin{array}{l}\text { The implementation of the IMCl } \\
\text { strategy in pediatric services } \\
\text { is an important instrument } \\
\text { for improving the degree of } \\
\text { knowledge by parents or } \\
\text { guardians. }\end{array}$ \\
\hline Prado, Fujimori(11) & $\begin{array}{l}\text { To identify maternal knowledge } \\
\text { regarding the care provided to } \\
\text { children with ARI or diarrhea } \\
\text { in units with the Family Health } \\
\text { Program (FHP) and without the } \\
\text { FHP, in Brazil. }\end{array}$ & $\begin{array}{l}\text { Cross-sectional } \\
\text { Descriptive- } \\
\text { exploratory }\end{array}$ & $\begin{array}{l}\text { The knowledge of the caregiver } \\
\text { was similar in both treatment } \\
\text { models with and without the FHP. }\end{array}$ & $\begin{array}{l}\text { It demonstrated the need to } \\
\text { improve communication with the } \\
\text { mother or family members, even } \\
\text { in the health units with FHP. }\end{array}$ \\
\hline $\begin{array}{l}\text { Irimu, Nduati, } \\
\text { Wafula, Lenja }{ }^{(12)}\end{array}$ & $\begin{array}{l}\text { To determine the perception of } \\
\text { a Kenyan community regarding } \\
\text { infantile pneumonia. }\end{array}$ & $\begin{array}{l}\text { Cross-sectional, } \\
\text { with an } \\
\text { ethnographic } \\
\text { approach. }\end{array}$ & $\begin{array}{l}\text { Pneumonia is perceived as one of } \\
\text { the most serious infantile disease. }\end{array}$ & $\begin{array}{l}\text { The perception of severe } \\
\text { pneumonia is consistent with } \\
\text { the definition of IMCI. The early } \\
\text { recognition of pneumonia by } \\
\text { caregivers and health workers is } \\
\text { essential to reduce mortality }\end{array}$ \\
\hline
\end{tabular}


(continuation)

\begin{tabular}{|c|c|c|c|c|}
\hline Author & Aims & Type of study & Results & Conclusions \\
\hline Paulo, Madeira(13) & $\begin{array}{l}\text { To comprehend what it means } \\
\text { to Brazilian mothers to have a } \\
\text { malnourished child. }\end{array}$ & $\begin{array}{l}\text { Phenomenological } \\
\text { study }\end{array}$ & Mothers felt guilty and impotent. & $\begin{array}{l}\text { It visualized new ways to teach/ } \\
\text { assist/care for the bi-nomial } \\
\text { mother-child, in experiencing } \\
\text { malnutrition. }\end{array}$ \\
\hline $\begin{array}{l}\text { Zaman, Ashraf, } \\
\text { Martines }^{(14)}\end{array}$ & $\begin{array}{l}\text { To determine the effectiveness } \\
\text { of the training of health } \\
\text { professionals in the } \mathrm{IMCl} \\
\text { nutrition counseling, aimed at } \\
\text { caregivers, in Pakistan. }\end{array}$ & Experimental & $\begin{array}{l}\text { The performance of the } \\
\text { professionals and the recall of } \\
\text { the caregivers were better in the } \\
\text { intervention group compared with } \\
\text { the control group. }\end{array}$ & $\begin{array}{l}\text { The IMCI training can improve } \\
\text { professional performance and } \\
\text { promote skills contributing to the } \\
\text { improvement of dietary practices } \\
\text { and the reduction of growth } \\
\text { retardation. }\end{array}$ \\
\hline $\begin{array}{l}\text { Pelto, Santos, } \\
\text { Gonçalves, Victora, } \\
\text { Martines, Habicht }{ }^{(15)}\end{array}$ & $\begin{array}{l}\text { To examine the professional } \\
\text { behavior and the retention of } \\
\text { nutritional guidance, by the } \\
\text { caregiver, as mediators of } \\
\text { the effectiveness of the } \mathrm{IMCl} \\
\text { nutrition counseling of the } \mathrm{IMCl} \text {, } \\
\text { in Brazil. }\end{array}$ & Experimental & $\begin{array}{l}\text { Trained physicians are more likely } \\
\text { to use communication skills and } \\
\text { perform nutritional counseling. } \\
\text { Mothers better recalled the } \\
\text { guidelines, except in relation to } \\
\text { breastfeeding, which did not differ } \\
\text { from the control group. }\end{array}$ & $\begin{array}{l}\text { The training of the professional } \\
\text { in IMCI includes the } \\
\text { development of communication } \\
\text { skills, use of appropriate } \\
\text { language and tools for the } \\
\text { individual approach to problems. }\end{array}$ \\
\hline $\begin{array}{l}\text { Santos, Victora, } \\
\text { Martines, } \\
\text { Gonçalves, Gigante, } \\
\text { Valle, Pelto et al }{ }^{(16)}\end{array}$ & $\begin{array}{l}\text { To evaluate the impact of } \\
\text { the nutritional counseling } \\
\text { component of IMCI in the } \\
\text { growth of Brazilian children. }\end{array}$ & Experimental & $\begin{array}{l}\text { Maternal practices and } \\
\text { professional performance were } \\
\text { higher in the intervention group } \\
\text { than the control. }\end{array}$ & $\begin{array}{l}\text { Training in nutrition counseling } \\
\text { increased the performance of } \\
\text { the physicians, the maternal } \\
\text { practices, the diet and weight } \\
\text { gain of children. }\end{array}$ \\
\hline $\begin{array}{l}\text { Cunha, Santos, } \\
\text { Martines }^{(17)}\end{array}$ & $\begin{array}{l}\text { To describe the process of } \\
\text { following the child in basic } \\
\text { health care units, where IMCI } \\
\text { was implemented, in Brazil. }\end{array}$ & Descriptive & $\begin{array}{l}56.9 \% \text { of the children attended the } \\
\text { follow-up. Reasons for absence } \\
\text { were: other family priorities and } \\
\text { the improvement of the child. }\end{array}$ & $\begin{array}{l}\text { Advising the caregiver about } \\
\text { the recognition of danger signs } \\
\text { and the need to return must } \\
\text { be reinforced with the team, } \\
\text { through training of the health } \\
\text { professionals. }\end{array}$ \\
\hline $\begin{array}{l}\text { Chopra, Patel, } \\
\text { Cloete, Sanders, } \\
\text { Peterson }^{(18)}\end{array}$ & $\begin{array}{l}\text { Measuring the change in the } \\
\text { quality of care provided to } \\
\text { sick South African children } \\
\text { as a result of the routine } \\
\text { implementation of IMCl. }\end{array}$ & $\begin{array}{l}\text { Quasi- } \\
\text { experimental, } \\
\text { pre and post- } \\
\text { intervention }\end{array}$ & $\begin{array}{l}\text { There were improvements in } \\
\text { the evaluation of danger signs, } \\
\text { rational prescribing and in the } \\
\text { initiation of treatment. There were } \\
\text { no changes in the treatment of } \\
\text { anemia, vitamin A prescription } \\
\text { and advice and knowledge of the } \\
\text { caregiver. }\end{array}$ & $\begin{array}{l}\mathrm{IMCl} \text { was associated with } \\
\text { important aspects of care for } \\
\text { sick children, provided that it is } \\
\text { developed in normal operational } \\
\text { conditions, in an environment } \\
\text { with good infrastructure and } \\
\text { support. }\end{array}$ \\
\hline $\begin{array}{l}\text { Kelly, Rowe, Onikpo, } \\
\text { Lama, Cokou, } \\
\text { Deming }^{(19)}\end{array}$ & $\begin{array}{l}\text { Studying the recall of caregivers } \\
\text { about the counseling messages } \\
\text { proposed by the IMCl in Benin. }\end{array}$ & Cross-sectional & $\begin{array}{l}\text { The number of recommendations } \\
\text { was on average } 38.7 \text { and the } \\
\text { percentage of recall was } 89.7 \% \\
\text { immediately after the consultation } \\
\text { and } 81.9 \% \text { after one day. }\end{array}$ & $\begin{array}{l}\text { The results confirm the need } \\
\text { to verify the understanding } \\
\text { of the caregiver regarding } \\
\text { recommendations, asking } \\
\text { them to repeat this, during the } \\
\text { consultation. }\end{array}$ \\
\hline $\begin{array}{l}\text { Lopez-Flores, } \\
\text { Barquera-Cervera, } \\
\text { Kageyama- } \\
\text { Escobar }^{(20)}\end{array}$ & $\begin{array}{l}\text { To determine the coverage } \\
\text { of IMCl and to estimate the } \\
\text { prevalence of malnutrition in } \\
\text { children aged } 6 \text { to } 36 \text { months of } \\
\text { age in urban areas of Mexico to } \\
\text { verify their association }\end{array}$ & Cross-sectional & $\begin{array}{l}\text { The coverage was } 97 \% \text { for } \\
\text { vaccination, } 66.9 \% \text { for vitamin } \\
\text { A supplementation, } 91.5 \% \text { for } \\
\text { the use of albendazole, } 50 \% \text { for } \\
\text { nutritional surveillance, } \\
25.5 \% \text { for parental training, } \\
24.4 \% \text { for health care of mothers } \\
\text { and } 2.5 \% \text { overall. Prevalence } \\
\text { of malnutrition was } 4.9 \% \text {, } \\
\text { significantly associated with } \\
\text { incomplete schemes, both of } \\
\text { vitamin A and of albendazole. }\end{array}$ & $\begin{array}{l}\text { The association of coverage of } \\
\mathrm{IMCl} \text { with malnutrition highlights } \\
\text { the importance of gathering } \\
\text { more evidence about its effect } \\
\text { on nutritional status, with } \\
\text { the aim of contributing to the } \\
\text { prevention and management of } \\
\text { infantile malnutrition. }\end{array}$ \\
\hline $\begin{array}{l}\text { Adegdoyega, } \\
\text { Onayade, Salawu } \\
(21)\end{array}$ & $\begin{array}{l}\text { To estimate the prevalence of } \\
\text { diseases addressed by the IMCI } \\
\text { and to determine the behavior } \\
\text { of searching for health services, } \\
\text { on behalf of Nigerian caregivers. }\end{array}$ & Cross-sectional & $\begin{array}{l}86.1 \% \text { of the children had } \\
\text { symptoms suggestive of malaria, } \\
\text { ARI, diarrhea or measles. The } \\
\text { search for care outside the } \\
\text { domicile was } 65.7 \% \text {, while } \\
\text { searching at the onset of } \\
\text { symptoms was only } 8.2 \% \text {. }\end{array}$ & $\begin{array}{l}\text { Diseases focused on in } \mathrm{IMCl} \\
\text { are prevalent in the study } \\
\text { population and the failure or } \\
\text { delay in seeking health services } \\
\text { can contribute to complicate the } \\
\text { condition. }\end{array}$ \\
\hline
\end{tabular}


(continuation)

\begin{tabular}{|l|l|l|l|l|}
\hline \multicolumn{1}{|c|}{ Author } & \multicolumn{1}{|c|}{ Aims } & \multicolumn{1}{c|}{ Type of study } & \multicolumn{1}{c|}{ Results } & \multicolumn{1}{c|}{ Conclusions } \\
\hline $\begin{array}{l}\text { Al Fadil, Alrahman, } \\
\text { Cousens, Bustreo, } \\
\begin{array}{l}\text { Shadoul, Farhoud, } \\
\text { et al(22) }\end{array}\end{array}$ & $\begin{array}{l}\text { To determine the extent to } \\
\text { which family members follow } \\
\text { the recommendations regarding } \\
\text { the child's referral and follow-up, } \\
\text { according to IMCl in Sudan }\end{array}$ & $\begin{array}{l}\text { Cross-sectional } \\
\text { Descriptive- } \\
\text { exploratory }\end{array}$ & $\begin{array}{l}\text { The adhesion to the initial referral } \\
\text { was } 33 \% \text { and to the follow- } \\
\text { up was 44\%. The reasons for } \\
\text { noncompliance were the cost, } \\
\text { improvement of the child. The } \\
\text { educational level of caregivers, } \\
\text { the start of the treatment at the } \\
\text { service and a prompt follow-up } \\
\text { promote adhesion. }\end{array}$ & $\begin{array}{l}\text { Starting treatment at the } \\
\text { health service and a more } \\
\text { prompt follow-up can improve } \\
\text { adherence to recommendations } \\
\text { of referral and follow-up of the } \\
\text { child in the context of IMCl. }\end{array}$ \\
\hline $\begin{array}{l}\text { Kalter, Salgado, } \\
\text { Moulton, Nieto, } \\
\text { Contreras, Egas, } \\
\text { et al (23) }\end{array}$ & $\begin{array}{l}\text { To identify factors involved in } \\
\text { the adherence of Ecuadorian } \\
\text { caregivers to the referral of the } \\
\text { child in the context of the IMCl. }\end{array}$ & Cross-sectional & $\begin{array}{l}\text { 42\% of the referred children were } \\
\text { not taken to hospital. Factors } \\
\text { involved: failure to instruct the } \\
\text { caregiver that the child should } \\
\text { be taken to hospital immediately, } \\
\text { access to the hospital, among } \\
\text { others. }\end{array}$ & $\begin{array}{l}\text { To provide a reference sheet } \\
\text { and instruct the caregiver } \\
\text { regarding the severity of illness } \\
\text { and need to take the child to } \\
\text { hospital immediately emerged } \\
\text { as powerful tools for the } \\
\text { successful referral of the child. }\end{array}$ \\
\hline
\end{tabular}

Figure 2 - Distribution of references showing authors, aims, type of study, results and conclusions

In the analysis of the results and conclusions of the studies selected, the most regular themes were: Acquisition of knowledge in IMCI and the perception of the caregivers; Training of health professionals in IMCI related to caregivers/mothers; Search for and adherence to health services by the caregivers.

\section{Acquisition of knowledge in $\mathrm{IMCl}$ and perception of the caregivers}

From interviews, the majority of the caregivers/ mothers name one or more warning signs for acute respiratory infection and recognize the practice of administration of fluids and maintenance of feeding during the course of this disease and also during acute diarrheal illness, however, regarding this disease caregivers/mothers interviewed did not know one or more warning signs ${ }^{(10)}$. Mothers were aware of the importance of providing fluids, but were unaware of the importance of the supply of food during diarrhea, conduct that must be maintained according to the IMCI strategy ${ }^{(11)}$.

Pneumonia is perceived as one of the most serious childhood illnesses, especially the following characteristics: changes in the thorax of the child, difficulty in respiration, presence of fever and convulsion. For caregivers the changes in the thorax, fever, difficulty in respiration commencing at night and seizures are indicative of serious illness, a term for rapid breathing not being found ${ }^{(12)}$.

The apprehending of accounts of care when the children have respiratory infections and diarrhea, in families within catchment areas of primary health care services, showed that the level of maternal and familial knowledge, in accordance with the purposes of the IMCI, was similar in the two assistance models, with and without the implementation of the family health program $^{(11)}$. The importance of detailed communication with mothers and family members was a highlighted point.

Malnutrition is reported by mothers as a concrete experience, punctuated by feelings of sadness, guilt, fear and suffering due to seeing the emaciated body of the child and comparing it to other healthy and strong children or siblings, and the uncertainty of illness and death. The mothers hope that the children can improve and restore their weight because they follow the guidelines regarding the diet of the child, and indicate that malnutrition is associated with lack or deficiency of food(13).

\section{Training of health professionals in $\mathrm{IMCl}$ related to caregivers/mothers}

With regard to the communicative abilities and performance of health workers there were significant differences between the health teams that received training in the IMCI strategy (intervention group) and those who did not (control group) ${ }^{(14-16)}$.

With regard to infant feeding, mothers in the intervention group presented significantly better recollection of the recommendations of health professionals and related dietary practices, even 180 days after the consultation. Actions, such as specific 
changes in inadequate practices, and explanation of why the changes should be made, were significantly more frequent in the intervention group ${ }^{(14)}$.

Physicians trained in the IMCI strategy were more likely to give nutritional advice, transmit more extensive opinions and use communication skills to improve and ensure the understanding of the mothers regarding nutritional advice. Correspondingly, the mothers in the intervention group had better recollection of messages about specific foods, adequate dietary practices and food preparation recommended by the trained physicians. In the recall of breastfeeding there was no significant difference between the two groups(15).

The recollection of the mothers and the satisfaction with the consultation were also higher in the intervention group, as well as an increase in the intake of recommended foods and a positive trend in weight gain in the children. This group also showed improved performance of health workers using good communication skills (to complimenting the caregiver, to question and listen, to use appropriate language, to praise the mothers and to check their comprehension) $)^{(16-17)}$.

In consultations held by nurses trained in the IMCI strategy, significant improvement was found in risk sign evaluation of sick children, evaluation of comorbidity, rational prescribing and initiation of treatment in the local health unit. There was a significant reduction in the inadequate use of antibiotics, especially in upper and lower respiratory tract illnesses. However, there was no change in the treatment of anemia or in the prescription of vitamin $A$, or in the advice to caregivers about this treatment. Also, there was no change in the knowledge of caregivers in relation to the comprehension of how to administer the prescribed medication or when to return to the health unit(18).

The recall and comprehension of the caregivers are important for disease prevention and in the treatment of the children, as well as for the promotion of their health, reinforcing the relevance of effective training of health professionals and the evaluation of the information

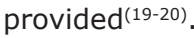

\section{Search for and adherence to health services by the caregivers}

The search for treatment for children with symptoms suggestive of acute respiratory infections, diarrhea, malaria and measles were analyzed based on how much their caregivers and/or mothers sought care outside the home. At the onset of symptoms the search for care outside the home was higher. In home- medication attempts, the use of traditional medicines and temporary treatment appeared ${ }^{(21)}$.

In situations of children with diseases prevalent in infancy, in service with the IMCI strategy, most caregivers were concerned with the health problem of the child, knew the day and time of the return follow-up and were satisfied with the consultation, few were not able to sufficiently show how to prepare and use the prescribed medications. Regarding the follow-up, the reasons for non-adherence to scheduled appointments, including children with pneumonia, acute ear infections, colds and diarrhea, were: the child had improved, other family commitments $^{(17)}$ and the cost of transportation ${ }^{(22)}$.

The domicile visit was a strategy to discover the reasons for non-adherence to the return to the health service and showed that, although most children had improved, some had a new health problem and were sick enough to be referred(17). The following of children's health is greater according to the higher education level of the caregiver, if the medications are given during the first consultation and if the follow-up is scheduled soon after ( 2 to 5 days) ${ }^{(22)}$.

In the treatment of diseases prevalent in infancy, according to the IMCI guidelines, improper prescription of antibiotics is also identified, being associated with an increased probability of a follow-up consultation ${ }^{(17)}$.

In the referral for emergency hospital care, in cases of diseases prevalent in infancy referred from primary care services, the following factors are highlighted for not accessing the hospital: perception of caregivers and decision making (did not see signs of the severity of the disease, the child not being sick enough to go to hospital, the cost of food and accommodation during the hospitalization, family dynamics); interaction with health services (workers did not say "go to hospital immediately", previous dissatisfaction with hospital evaluation and negative experience with the service); access to the hospital and financial and physical barriers (geography, and costs of transportation). When caregivers received guidance to seek the hospital immediately from the primary health care workers and the referral given at the initiation of the consultation there was a reduction in non-access of the hospitals(23).

\section{Discussion}

The main causes of mortality of children under five years of age continue to be the perinatal diseases, pneumonia, diarrheal disease complications and malnutrition ${ }^{(2)}$. In the studies selected, the acquisition 
of knowledge by caregivers and mothers was identified, especially regarding the warning signs of infectious diseases and the perceived characteristics of some respiratory diseases, diarrhea and malnutrition.

Some studies highlighted inadequate knowledge and perceptions of the family which could base detrimental procedures in domicile care for the sick child, such as to reduce the dietary supply during the course of diarrhea(11), to fail to seek help in the health service due to not recognizing signs of pneumonia(12) and warning signs of diarrhea(10), and to wean the child early because of the belief that prolonged breastfeeding might predispose it to malnutrition ${ }^{(13)}$.

Studies show that training in IMCI improves the performance of health teams, the understanding and practices of caregivers, especially with regard to the advice to the caregiver ${ }^{(14-17,20)}$, assessment of the risk signs of sick children, evaluation of co-morbidity, appropriate prescription of medication, and early treatment in the local health unit(18). The detailed communication with mothers and family members is an important point in making the IMCI strategy operational(11). According to the recommendation of the strategy, it is crucial to ask several questions of the mother or caregiver, to listen carefully to their responses in order to provide relevant recommendations, to offer praise for having followed appropriate practices, to guide the practices that need improvement, to employ simple language so they can understand, and to elaborate verification questions to make sure they can take care of the child at home ${ }^{(25)}$.

The importance of communication is also highlighted in the adherence to follow-up and the referral of the child. Although influenced by factors such as the perception of caregivers about the signs of severity of the disease, the improvement of the child, the cost of food and accommodation during hospitalization, geographic barriers and family dynamics, the adhesion also suffered influence from the interaction with the health services, highlighting the lack of clarity in the guidelines for referral and follow-up, on behalf of the workers, and dissatisfaction of the users with previous hospital evaluations and negative experiences with the service ${ }^{(17,21-23)}$.

The relationship between professionals and caregivers thus emerges as the core of this literature review on the prevention, promotion and treatment of diseases prevalent in infancy. For this relationship to be configured as an effective therapeutic relationship it is necessary to use the communication skills recommended by the IMCI, but not limited to the protocol. It requires an open and true approach of caregivers from health professionals, marked by horizontality and by the sharing of experiences.

\section{Final considerations}

From the analyzed studies it was possible to apprehend the need for professional commitments with the integral health of the child focused on the care, to comprehend the needs and rights of the child and the family, emphasizing the responsibility to provide qualified and humanized health care.

The assistance provided in health services may have a limited impact if it does not consider that the guardians and caregivers play a key role in the recovery, maintenance and protection of the health of the child in the domicile. In the health of the child it is extremely relevant to focus the IMCI strategy, encouraging discussions and experiences that involve the family in the care, amplifying communication, comprehension and intervention in the health-disease and care process.

The communicative and empathic attitude of the professionals, associated with the IMCI strategy, contributes significantly to an effective integration between practical and technical-scientific knowledge. This integration has been little explored in the articles analyzed, because most of them highlight the performance of professional in advising and the capacity of the caregiver to remember and follow the guidelines, without addressing the factors involved in the quality of the established relationship and its influence in the care of the child. These aspects deserve to be explored in future research on prevention, promotion and treatment of the diseases prevalent in infancy.

\section{References}

1. Pan American Health Organization, World Health Organization. Integrated Management of Childhood Illness (IMCI). In: Final report of the 26th Pan American Sanitary Conference; 23-27 September 2002; Washington, D.C, USA. Washington, D.C.: OPAS/OMS; 2002. p. 17-8.

2. Cunha AJLA, Benguigui Y, Silva MASF. Atenção integrada às doenças prevalentes na infância: implantação e avaliação no Brasil. Rio de Janeiro: Fiocruz; 2006.

3. Ministério da Saúde (BR), Organização Pan-Americana da Saúde, Organização Mundial da Saúde. AIDPI Atenção integrada às doenças prevalentes na infância: curso de capacitação: introdução: módulo 1. 2. ed. Brasília, DF: Ministério da Saúde; 2003. 
4. Organização Pan-Americana da Saúde, Organização Mundial da Saúde. Melhorando a saúde das crianças: o enfoque integrado. Brasília, DF: OPAS/OMS; 2000.

5. Benguigui Y. Perspectivas en el control de enfermedades en los niños: atención integrada a las enfermedades prevalentes de la infância. Rev Bras Saúde Mater Infant. 2001;1(1):7-19.

6. Ministério da Saúde (BR). Secretaria de Políticas de Saúde. AIDPI Atenção Integrada às Doenças Prevalentes na Infância: curso de capacitação: avaliar e classificar a criança de 2 meses a 5 anos de idade: módulo 2. 2. ed. Brasília (DF): Ministério da Saúde; 2003.

7. Flores-Peña Y, Gala SEVR, Cerda-Flores RM. Satisfação materna com o cuidado da enfermeira materno-infantil em Campeche, México. Rev. Latino-Am. Enfermagem [internet] 2009 [acesso: 28 jun 2010]; 17(5). Disponível em: www.eerp.usp.br/rlae.

8. Mello DF, Lima RAG, Scochi CGS. A saúde de crianças em situação de pobreza: entre a rotina e a eventualidade de cuidados cotidianos. Rev. Latino-Am. Enfermagem [internet]. 2007 [acesso: 28 jun 2010];15(número especial). Disponível em: www.eerp.usp.br/rlae.

9. Mendes KDS, Silveira RCCP, Galvão CM. Revisão integrativa: método de pesquisa para a incorporação de evidências na saúde e na enfermagem. Texto \& Contexto Enferm. 2008; 17(4):58-64.

10. Amorin CSC, Damasceno ACAD, Trindade CF, AbenAthar SB. Conhecimento pelos pais sobre os sinais de alarme em infecção respiratória aguda e doença diarréica aguda em menores de 5 anos. Rev Paranaense Med. $2006 ; 20(1): 27-31$.

11. Prado SRLA, Fujimori E. Conhecimento materno/ familiar sobre o cuidado prestado à criança doente. Rev Bras Enferm. 2006;59(4):492-6.

12. Irimu G, Nduati RW, Wafula E, Lenja J. Community understanding of pneumonia in Kenya. Afr Health Sci. 2008;8(2):103-7.

13. Paulo IMA, Madeira AMF. Ter um filho desnutrido: - significado para as mães. Rev Min Enferm. 2006;10(1):12-7.

14. Zaman S, Ashraf RN, Martines J. Training in complementary feeding counseling of healthcare workers and its influence on maternal behaviours and child growth: a cluster randomized controlled trial in Lahore, Pakistan. J Health Popul Nutr. 2008;26(2):210-22.

15. Pelto GH, Santos I, Gonçalves H, Victora C, Martines J, Habicht J. Nutrition counseling training changes physician behavior and improves caregiver knowledge acquisition. J Nutr. 2004;134(2):357-62.
16. Santos I, Victora CG, Martines J, Gonçalves $\mathrm{H}$, Gigante DP, Valle NJ, et al. Nutrition counseling increases weight gain among Brazilian children. J Nutr. 2001;131(11):2866-73.

17. Cunha AJLA, Santos SR, Martines J. Integrated care of childhood disease in Brazil: Mothers' response to the recommendations of health workers. Acta Paediatr. 2005; 94(8):1116-21.

18. Chopra M, Patel S, Cloete K, Sanders D, Peterson S. Effect of an IMCI intervention on quality of care across four districts in Cape Town, South Africa. Arch Dis Child. 2005; 90(4):397-401.

19. Kelly JM, Rowe AK, Onikpo F, Lama M, Cokou $F_{\text {, }}$ Deming MS. Care takers' recall of Integrated Management of Childhood Illness counseling messages in Benin. Trop Doct. 2007; 37(2):75-9.

20. López-Flores F, Barquera-Cervera S, KageyamaEscobar ML. Evaluación de una atención integrada contra la desnutrición infantil en áreas urbanas de Nayarit, México. Salud Pública Méx. 2004;46(2):158-63.

21. Adegboyega AA, Onayade AA, Salawu O. Careseeking behavior of caregivers for common childhood illnesses in Lagos Island Local Government Area, Nigeria. Niger J Med. 2005;14(1):65-71.

22. Al Fadil SM, Alrahman SHA, Cousens S, Bustreo F, Shadoul A, Farhoud $S$, et al. Integrated Management of Childhood Illnesses strategy: compliance with referral and follow-up recommendations in Gezira State, Sudan. Bull World Health Organ. 2003;81(10):708-16.

23. Kalter HD, Salgado R, Moulton LH, Nieto $P$, Contreras $A$, Egas $M L$, et al. Factors constraining adherence to referral advice for severely ill children managed by the Integrated Management of Childhood Illness approach in Imbabura Province, Ecuador. Acta Paediatr. 2003;92(1):103-10.

24. Broome ME. Integrative literature reviews for the development of concepts. In: Rodgers BL, Knaf KA. Concept development in nursing: foundations, techniques and applications. 2. ed. Philadelphia: WB Saunders; 2000. p. 193-215.

25. Ministério da Saúde (BR). AIDPI Atenção Integrada às Doenças Prevalentes na Infância: curso de capacitação: aconselhar a mãe ou o acompanhante: módulo 5. 2.ed. Brasília (DF): Ministério da Saúde; 2002.

Received: Sep. 30 2009 Accepted: Ago. $4^{\text {th }} 2010$ 